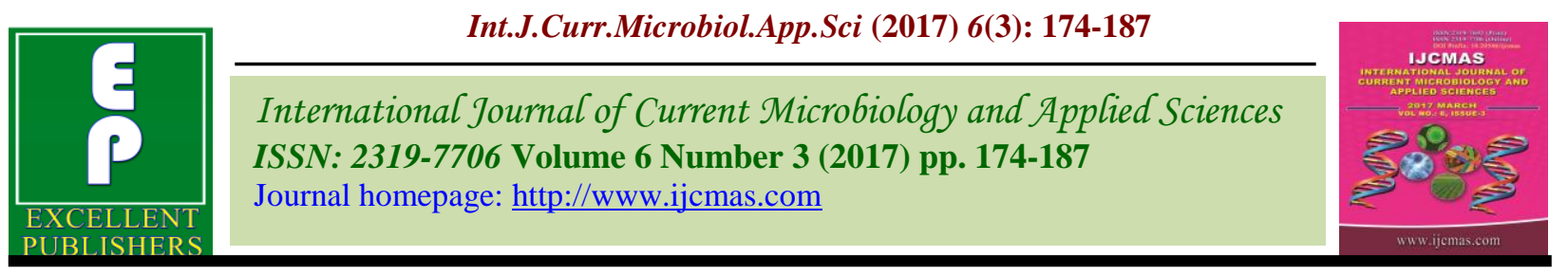

Original Research Article https://doi.org/10.20546/ijcmas.2017.603.019

\title{
Deproteinated Cheese Whey Medium for Biomass Production of Probiotic Lactobacillus helveticus MTCC 5463
}

\author{
Salma*, J.B. Prajapati, Subrota Hati, V. Sreeja and Jigar Trivedi \\ Dairy Microbiology Department, SMC College of Dairy Science, AAU, Anand, Gujarat, India \\ *Corresponding author
}

A B S T R A C T

Keywords

Lactobacillus

helveticus MTCC

5463, Probiotic

biomass, Response

surface methodology, Whey.

Article Info

Accepted:

08 February 2017

Available Online:

10 March 2017

\begin{abstract}
Deproteinated cheese whey was used for biomass production of probiotic strain Lactobacillus helveticus MTCC 5463 in a biofermenter. Optimization of growth parameters such as temperature, $\mathrm{pH}$ and time of incubation as well as nutrient supplementation of cheese whey was carried out using response surface methodology (RSM). Cheese whey supplemented with $0.95 \%$ yeast extract and $0.95 \%$ proteose peptone, inoculated with $6 \%(\mathrm{v} / \mathrm{v})$ active culture of L. helveticus MTCC 5463 and fermented for $24 \mathrm{~h}$ at optimized temperature of $40^{\circ} \mathrm{C}$ and $\mathrm{pH} 6.25$ yielded $3.25 \mathrm{~g} / \mathrm{L}$ dry cell biomass and $14.82 \mathrm{log}$ cfu/g total viable count. The optimization of growth parameters and nutrient supplementation resulted in an increase of biomass yield from 1.997 to $3.25 \mathrm{~g}$ DCW/L, an enhancement $62.74 \%$.
\end{abstract}

\section{Introduction}

Owing to positive modulation of intestinal microbiota by probiotic, consumer's interest has sharply grown towards various probiotic foods. Probiotics are defined as 'live microorganisms which when administered in adequate amounts confer a health benefit on the host' (FAO/WHO, 2002). The major group of probiotic bacteria belongs to the species of Lactobacilli and Bifidobacteria. There has also been growing interest in the use of probiotic lactic acid bacteria for a wide range of applications in food, pharmaceuticals and health products. The large scale production of the cell biomass of the probiotic organism is therefore necessitated to cater the industry to meet the growing demand. It is therefore important to standardize the process (upstream and downstream processing) and optimize each processing parameters (temperature, $\mathrm{pH}$ and time) of fermentation for yielding maximum cell biomass. Also designing of alternative low cost cultivation medium for biomass production could be useful for the large scale production of probiotic strain for its commercial application.Several workers have reported effects of growth parameters and media supplementation on growth of lactic acid bacteria and its subsequent viability (Liu et al., 2010; Aguirre-Ezkauriatza et al., 2010; Mondragón-parada et al., 2006). Attempts have been made to optimize the fermentation 
parameters and media composition in order to obtain highest microbial mass from LAB using RSM (Bevilacqua et al., 2008; PolakBerecka et al., 2010; Lechiancole et al., 2002).

Whey is the major by-product obtained during the preparation of dairy products such as cheese, channa, paneer, and shrikhand. It is a rich source of whey proteins, lactose, enzymes, vitamins, bioactive compounds and minerals (Agrawal et al., 1989). Availability of lactose in whey and presence of essential nutrients for the growth of microorganisms makes whey one of the most potent raw materials for the production of different byproducts through different biotechnological applications (Panesar et al., 2007). Also, many small-size cheese plants do not have proper treatment systems for the disposal of whey and the dumping of whey constitutes a significant loss of potential food as whey retains about $40-45 \%$ of total milk solids (Panesar et al., 2006).

Whey disposal poses serious pollution problems for the dairy industry to the surrounding environment because of quite high biological oxygen demand i.e. approx. 30000-50000 ppm (Gupte and Nair, 2010). In this context, fermentation of whey using LAB to produce the biomass is one of the novel ways to utilize this dairy by-product that further broadens the market potentiality of whey (Ghanadzadeh et al., 2012). Whey has been used to culture lactic bacteria, but mainly for lactic acid production rather than biomass generation (Lund et al., 1992; Youssef and Goma, 2005; Shahbazi et al., 2005; Altiok et al., 2006; Panesar et al., 2007; Agarwal et al., 2008). Richardson et al., (1977) pioneered work on the use of whey as a low-cost alternative medium for the propagation of lactic starter cultures for cheese makers. The present study is therefore planned to optimize fermentation parameters for the production of cell biomass of Lactobacillus helveticus MTCC 5463 in cheese whey at pilot scale.

\section{Materials and Methods}

\section{Materials and Media}

All chemicals and reagents were of at least analytical grade and supplied by SigmaAldrich (Mumbai, India) unless specified. All the media used for enumeration of bacteria were purchased from Himedia (Mumbai, India). Unsalted cheddar cheese whey $(\mathrm{CW})$ was procured from VidyaDairy (Anand, India). Skimmilk powder (Sagar) was purchased from local super market (Anand, India).

\section{Bacterial strain}

Pure strains of L. helveticus MTCC 5463 was provided by Department of Dairy Microbiology, AAU (Anand, India). Lb.helveticus MTCC 5463 (earlier known as Lb. acidophilus V3) strain was originally isolated from vaginal tract of a healthy adult female in India at Gujarat Agricultural University (Khedkar et al., 1991). Based on the studies of its biochemical characteristics, it showed ability to grow in the presence of $0.3 \%$ sodium taurocholate, deconjugate bile acids, and reduce cholesterol in vitro (Ashar and Prajapati, 1998). A hypocholesterolemic effect of L. helveticus MTCC 5463 was reported in human subjects with different cholesterol levels (Ashar and Prajapati, 2000). A maximum reduction of $21 \%$ was observed in volunteers having cholesterol level of 200$220 \mathrm{mg} / \mathrm{dl}$ suggesting the potential of the strain in preventing the risk of coronary heart diseases. The strain exhibited significant antimicrobial activity against Bacillus cereus, Staphylococcus aureus, Pseudomonas aeruginosa, Salmonella enteric serovar typhi, and Escherichia coli (Khedkar et al., 1990). 
The strain produced extracellular polysaccharide and was able to adhere to cells of the human carcinoma cell line HT29 (Vishwanath et al., 2012). Other than this a number of probiotic and synbiotic milk based products have already been developed using this strain.

The strain was activated from its frozen form (stored in $10 \%$ glycerol at $-80{ }^{\circ} \mathrm{C}$ ) by giving one transfer in MRS broth. This was followed by 2 successive transfers into sterile MRS broth, followed by 2 transfers into sterile whey, under incubation conditions of $37^{\circ} \mathrm{C}$ for $12 \mathrm{~h}$.

\section{Optimization of the inoculum rate}

Pure strain of L. helveticus MTCC 5463 was grown overnight for $24 \mathrm{~h}$ in MRS broth. Subsequently it was inoculated at $2 \%, 4 \%$, $6 \%, 8 \%$ and $10 \%(\mathrm{v} / \mathrm{v})$ rate in to MRS broth. All the flasks were incubated at $37^{\circ} \mathrm{C}$ for 24 h. After incubation, samples were taken from each flask to analyze the biomass. The cells were harvested from fermented media by centrifugation at $6000 \mathrm{xg}$ for $20 \mathrm{~min}$ at $4{ }^{\circ} \mathrm{C}$ (REMI C30, India). Cell pellet of the lactobacilli were washed twice with saline $(0.85 \% \mathrm{w} / \mathrm{v})$ and the wet yield was determined gravimetrically and expressed as $\mathrm{g} / \mathrm{L}$. Total viable counts of lactobacilli were measured using MRS Agar and expressed as $\log \mathrm{cfu} / \mathrm{ml}$ (De Man et al.,1960).

\section{Optimization of growth parameters and media composition}

$\mathrm{CW}$ was subjected to indirect heating at $92^{\circ} \mathrm{C}$ for $20 \mathrm{~min}$ in order to remove whey proteins by thermo coagulation and filtration of precipitate. The deproteinized whey was autoclaved and used as base media. Batch experiments were conducted in a fully automatic fermenter (Shree Biocare, India). Base media was inoculated with $6 \%(\mathrm{w} / \mathrm{v})$ pure strain of L. helveticus MTCC 5463 and fermented in batch fermenter in $\mathrm{pH}$ controlled condition. Sodium hydroxide solution $(6 \mathrm{~N})$ and hydrochloric acid solution $(6 \mathrm{~N})$ were automatically fed at $0.3 \mathrm{ml} / \mathrm{min}$ flow rate using peristaltic pump. The speed of agitator was fixed at $80 \mathrm{rpm}$ and the dissolved oxygen content was kept below 20\%. Optimization of incubation time, temperature and $\mathrm{pH}$ were done using response surface methodology (RSM). The experiments were carried out with total 20 different combinations of temperature $\left(35^{\circ} \mathrm{C}-45^{\circ} \mathrm{C}\right), \mathrm{pH}(5.5-6.5)$ and incubation period $(12 \mathrm{~h}-24 \mathrm{~h})$ as suggested by Design - Expert (ver. 9.0.2). Similarly, optimization of nutrients (yeast extract and proteose peptone) supplementation level was also done using RSM. The experiments were carried out with total of 13 different combinations of yeast extract $(0.1$ to $1 \%, \mathrm{w} / \mathrm{v})$ and proteose peptone $(0.5-1 \%, \mathrm{w} / \mathrm{v})$ as suggested by Design - Expert (ver. 9.0.2). Samples were collected from $1 \mathrm{~L}$ of thoroughly mixed fermented media from bioreactor to determined viability and total biomass yield of L. helveticus MTCC 5463.

\section{Experimental design}

In the optimization of growth parameters, independent variables were $\mathrm{pH}$, temperature and time of fermentation. Whereas in nutrient supplementation, the independent variables were Yeast extract (YE) and Proteose peptone (PP). For both the experiments, central composite rotatable design (CCRD) of Response Surface Methodology (RSM) using Design - Expert (ver. 9.0.2) was used. In the optimization process the response can be related to chosen factors by linear or quadratic models. Adequacy of model was evaluated using F-ratio and coefficient of determination $\left(\mathrm{R}^{2}\right)$. Model was considered adequate when Fcalculated was more than tabulated $\mathrm{F}$ value and $\mathrm{R}^{2}$ was more than $80 \%$. The analysis of variance (ANOVA) tables were generated and 
the effect of variables at linear, quadratic and interactive level on the individual response was described using significance at $5 \%$ levels of significance.

\section{Statistical analysis}

Data were subjected to statistical analysis using completely randomized design (CRD). The significance was tested at $5 \%$ level of significance using mean value, co-efficient of variance (C.V) and critical difference (C.D).Values with $\mathrm{P}<0.05$ were considered statistically significant. Whereas for the optimization study, Central Composite Rotatable Design (CCRD) of response surface methodology were performed using Designed expert 9.0.2 software package.

\section{Results and Discussion}

To measure the growth of $L$. helveticus MTCC 5463in three different media (MRS, Skim milk and Cheese whey), total viable counts and changes in $\mathrm{pH}$ were monitored after every 6 hours of incubation at $37^{\circ} \mathrm{C}$ for initial $24 \mathrm{~h}$ and then at an interval of $12 \mathrm{~h}$ up to $120 \mathrm{~h}$. The initial $\mathrm{pH}$ of the media was adjusted to 6.5 and the inoculation rate was kept constant at $6 \%(\mathrm{v} / \mathrm{v})$ as optimized. The growth pattern and changes in $\mathrm{pH}$ are shown in figure 1 and 2 respectively.

Viable cell count clearly indicated that $L$. helveticus MTCC 5463 could efficiently grow in all the three media. Changes in cell concentration $(\log \mathrm{cfu} / \mathrm{ml})$ in milk, whey and MRS media was found to be significantly $(\mathrm{P}<0.05)$ different irrespective of time. Among them the mean viable cell count was highest in MRS broth $(9.12 \log \mathrm{cfu} / \mathrm{ml})$ followed by Skim milk (9.03 $\log \mathrm{cfu} / \mathrm{ml})$ and cheese whey $(8.72 \log \mathrm{cfu} / \mathrm{ml})$.The mean viable count, irrespective of the media, reached at the peak after $12 \mathrm{~h}$ of incubation $(9.3 \log \mathrm{cfu} / \mathrm{ml})$ which remained statistically unchanged $(\mathrm{P}>0.05)$ till $84 \mathrm{~h}$ of incubation. This indicated that the average stationary phase in all the three media ranged from $12 \mathrm{~h}$ $84 \mathrm{~h}$. However there was significant decline at $96 \mathrm{~h}$ of incubation. The interaction effect of period of incubation and the media was nonsignificant but there was not much difference in the viable cell count at $12 \mathrm{~h}$ in all the three media. The rate of increase was very slow after $24 \mathrm{~h}$ of incubation and hence it is not recommended to incubate the culture for more than $24 \mathrm{~h}$ for harvesting the cells.

During fermentation the $\mathrm{pH}$ declined continuously with the increase in incubation period in all the three media as depicted in figure 2. The average change in $\mathrm{pH}$ was comparable in milk and whey which was significantly $(\mathrm{P}<0.05)$ lower than MRS broth. The average decline in $\mathrm{pH}$ drop was significant at every period of estimation up to 18 h. However further decline was comparable between $24 \mathrm{~h}$ to $36 \mathrm{~h}, 36 \mathrm{~h}$ to 60 $\mathrm{h}, 48 \mathrm{~h}$ to $72 \mathrm{~h}, 60 \mathrm{~h}$ to $96 \mathrm{~h}$ and $72 \mathrm{~h}$ to $120 \mathrm{~h}$. The interaction effect of period and media was also significant. At the end of $24 \mathrm{~h}$, the $\mathrm{pH}$ of whey and MRS medium was comparable but that of milk was significantly lower. The decline of $\mathrm{pH}$ in first two hours was maximum in whey followed by MRS and milk which indicated that culture enters into log phase in whey more rapidly as compared to other media.

\section{Optimization of growth parameters}

An RSM experiment was framed on the Central Composite Rotatable Design (CCRD) with three factors viz. $\mathrm{pH}$, time and temperature of fermentation. The 20 experiments so generated by the Design Expert 9.0.2 software as shown in table 1 were run and the corresponding response in terms of total viable count (TVC) $\log \mathrm{cfu} / \mathrm{g}$ and Dry Biomass yield $\mathrm{g} / \mathrm{L}$ was obtained after running the trials in biofermenter. 


\section{Effect on TVC}

The average TVC of $L$. helveticus MTCC 5463 varied from 9.73 to $13.29 \mathrm{log} \mathrm{cfu} / \mathrm{g}$. Viability of cells was minimum when the strain was grown in cheese whey at $45^{\circ} \mathrm{C}$ for $12 \mathrm{~h}$ with constant maintenance of $\mathrm{pH}$ at 6.0 whereas maximum TVC were observed when the strain was grown in cheese whey at $40{ }^{\circ} \mathrm{C}$ for $18 \mathrm{~h}$ with constant maintenance of $\mathrm{pH}$ at 6.5 as presented in table 1 . Surface response for effect of different growth parameters on TVC of L. helveticus MTCC 5463 grown in cheese whey is shown in figure 3 . Better fit of quadratic model for TVC of the L. helveticus MTCC 5463 was explained on the basis of regression analysis of the data presented in table 1. Coefficient of determination $\left(\mathrm{R}^{2}\right)$ of 0.8734 is in close agreement with adjusted $R^{2}$ of 0.7594 . This validates experimental and predicted levels of total viable counts. Higher model $F$ value (7.66) than tabulated $F$ value supported the significance of model for predicting the effect of variables on TVC of L. helveticus MTCC 5463. Furthermore, higher adequate precision value (APV) (7.290) than required value (4.00) indicated the high and adequate prediction ability of the model.

Multiple regression equation generated to predict the TVC as affected by different factors in terms of coded factor is given below:

Total viable counts $=+13.32+0.19 *$ A- $0.059 *$ $\mathrm{B}-0.37 * \mathrm{C}+0.11^{*} \mathrm{AB}-0.18^{*} \mathrm{AC}+0.61 * \mathrm{BC}-$ $0.44 * \mathrm{~A}^{\wedge} 2-0.88^{*} \mathrm{~B}^{\wedge} 2-0.85^{*} \mathrm{C}^{\wedge} 2$

\section{Effect on biomass}

Biomass yield of L. helveticus MTCC 5463is shown in table 1 . Cheese whey inoculated (18 $\mathrm{h}$ fermentation time) with $L$. helveticus MTCC 5463 and incubated at $32{ }^{\circ} \mathrm{C}$ and 6.5 $\mathrm{pH}$ showed minimal dry biomass yield of 0.10 $\mathrm{g} / \mathrm{L}$ whereas maximum dry biomass yield of
$2.63 \mathrm{~g} / \mathrm{L}$ was found at $40{ }^{\circ} \mathrm{C}$ for 28 hours and at $\mathrm{pH}$ 6.5. The regression analysis of the data presented in table 2 indicated that the coefficient of determination $\left(\mathrm{R}^{2}\right)$ was 0.8808 and that the model was significant. The ANOVA of quadratic model showed that model $\mathrm{F}$ value of 8.21 was more than the tabulated value. Adequate precision value (APV) was 10.435, which was significantly higher than minimum desirable (4.00) for high prediction value. All these parameters showed that the model can be used to describe the effect of variables on biomass production of L. helveticus MTCC 5463 grown in cheese whey.

Multiple regression equation generated to predict the biomass yield as affected by different factors in terms of coded factor is given below:

Biomass yield $=1.73+0.24^{*} \mathrm{~A}+0.16^{*} \mathrm{~B}-$ $0.33^{*} \quad \mathrm{C}-0.15^{*} \quad \mathrm{AB} 5.27 \mathrm{E}-03 * \quad \mathrm{AC}-0.16^{*}$ $\mathrm{BC}+0.06^{*} \mathrm{~A}^{\wedge} 2-0.49^{*} \mathrm{~B}^{\wedge} 2-0.12 * \mathrm{C}^{\wedge} 2$

Positive coefficient estimate of fermentation time (Table 2) indicates that it had significant $(\mathrm{P}<0.01)$ positive effect on biomass yield at linear level. It means with increase in the fermentation period, biomass yield from $L$. helveticus MTCC 5463 increases. Also pH has significant $(\mathrm{P}<0.05)$ effect on biomass yield. The interaction effect of all the variables in cheese whey fermentation showed non-significant effect on biomass yield. However, at quadratic level, effects of all variables were non-significant except for temperature. The surface responses for interactive effect of variables on biomass yield are shown in figure $4(a, b, c)$.

Current study results have shown that the physical growth parameters such as time, temperature of incubation and $\mathrm{pH}$ of fermentation medium has definite significant effect on production of biomass and survivability of the strain. 
Table.1 Combinations generated by RSM for optimization of growth parameters

\begin{tabular}{|c|c|c|c|c|c|}
\hline & Factor 1 & Factor 2 & Factor 3 & Response 1 & Response 2 \\
\hline Run & $\begin{array}{l}\text { A:Time } \\
\text { H }\end{array}$ & $\begin{array}{l}\text { B:Temp } \\
{ }^{\circ} \mathrm{C}\end{array}$ & C:pH & $\begin{array}{l}\text { Dry Biomass } \\
\text { Yield } \\
\text { g/L }\end{array}$ & $\begin{array}{l}\text { TVC } \\
\log \mathrm{cfu} / \mathrm{g}\end{array}$ \\
\hline 1 & 28 & 40 & 6.5 & 2.63 & 13.05 \\
\hline 2 & 18 & 40 & 6.5 & 2.15 & 13.29 \\
\hline 3 & 24 & 35 & 6 & 1.64 & 11.85 \\
\hline 4 & 18 & 40 & 7.3 & 1.28 & 10.77 \\
\hline 5 & 18 & 40 & 6.5 & 1.63 & 13.29 \\
\hline 6 & 18 & 40 & 6.5 & 1.61 & 13.22 \\
\hline 7 & 18 & 48 & 6.5 & 0.85 & 11.47 \\
\hline 8 & 24 & 45 & 6 & 1.75 & 10.93 \\
\hline 9 & 12 & 45 & 6 & 1.86 & 9.73 \\
\hline 10 & 24 & 35 & 7 & 0.92 & 9.95 \\
\hline 11 & 18 & 40 & 6.5 & 1.63 & 13.28 \\
\hline 12 & 8 & 40 & 6.5 & 1.45 & 12.28 \\
\hline 13 & 18 & 40 & 6.5 & 1.64 & 13.19 \\
\hline 14 & 24 & 45 & 7 & 0.65 & 10.84 \\
\hline 15 & 18 & 40 & 6.5 & 1.62 & 13.27 \\
\hline 16 & 12 & 45 & 7 & 0.49 & 10.96 \\
\hline 17 & 12 & 35 & 7 & 0.40 & 9.91 \\
\hline 18 & 12 & 35 & 6 & 0.89 & 11.72 \\
\hline 19 & 18 & 40 & 5.7 & 1.81 & 12.27 \\
\hline 20 & 18 & 32 & 6.5 & 0.10 & 11.37 \\
\hline
\end{tabular}

Table.2 Regression coefficients and ANOVA of fitted quadratic model for total viable count and dry biomass yield of L. helveticus MTCC 5463 grown in cheese whey

\begin{tabular}{|l|l|l|}
\hline Partial Coefficients & $\begin{array}{l}\text { Dry biomass } \\
\text { yield }\end{array}$ & TVC \\
\hline Intercepts & 1.73 & 13.32 \\
\hline A- Time of fermentation & $0.24^{*}$ & $0.19^{\mathrm{NS}}$ \\
\hline B-Temperature of fermentation & $0.16^{\mathrm{NS}}$ & $-0.059^{\mathrm{NS}}$ \\
\hline $\mathrm{C}-\mathrm{pH}$ of fermentation & $-0.33^{*}$ & $-0.37^{\mathrm{NS}}$ \\
\hline $\mathrm{AB}$ & $-0.15^{\mathrm{NS}}$ & $0.11^{\mathrm{NS}}$ \\
\hline $\mathrm{AC}$ & $5.27 \mathrm{E}-03^{\mathrm{NS}}$ & $-0.18^{\mathrm{NS}}$ \\
\hline $\mathrm{BC}$ & $-0.16^{\mathrm{NS}}$ & $0.61^{*}$ \\
\hline $\mathrm{A}^{2}$ & $0.06^{\mathrm{NS}}$ & $-0.44^{*}$ \\
\hline $\mathrm{B}^{2}$ & $-0.49^{*}$ & $-0.88^{*}$ \\
\hline $\mathrm{C}^{2}$ & $-0.12^{\mathrm{NS}}$ & $-0.85^{*}$ \\
\hline Model F & 8.21 & $7.66^{*}$ \\
\hline $\mathrm{R}^{2}$ & 0.8808 & 0.8734 \\
\hline APV & 10.432 & 7.29 \\
\hline
\end{tabular}

** Significant at $1 \%$ level $(\mathrm{P}<0.01), *$ Significant at $5 \%$ level $(\mathrm{P}<0.05)$, NS: Non-significant 
Table.3 Combinations generated by RSM for optimization of nutrient supplementation

\begin{tabular}{|c|c|c|c|c|}
\hline \multirow[b]{2}{*}{ Run } & Factor 1 & Factor 2 & Response 1 & Response 2 \\
\hline & $\begin{array}{l}\text { A:YE } \\
\%\end{array}$ & $\begin{array}{l}\text { B:PP } \\
\%\end{array}$ & $\begin{array}{l}\text { Yield } \\
\text { g/L }\end{array}$ & $\begin{array}{l}\text { TVC } \\
\text { Log cfu/g }\end{array}$ \\
\hline 1 & 0.03 & 0.75 & 2.186 & 13.21 \\
\hline 2 & 0.6 & 0.75 & 3.244 & 15.11 \\
\hline 3 & 0.6 & 0.75 & 3.103 & 15.24 \\
\hline 4 & 1 & 0.5 & 2.997 & 14.23 \\
\hline 5 & 0.2 & 1 & 2.374 & 14.02 \\
\hline 6 & 0.6 & 1.1 & 2.978 & 15.26 \\
\hline 7 & 0.2 & 0.5 & 2.685 & 14.47 \\
\hline 8 & 0.6 & 0.4 & 2.828 & 15.12 \\
\hline 9 & 0.6 & 0.75 & 3.018 & 15.48 \\
\hline 10 & 0.6 & 0.75 & 3.244 & 15.68 \\
\hline 11 & 0.6 & 0.75 & 3.243 & 15.98 \\
\hline 12 & 1 & 1 & 3.622 & 14.85 \\
\hline 13 & 1.17 & 0.75 & 3.310 & 15.53 \\
\hline
\end{tabular}

Table.4 Regression coefficients and ANOVA of fitted quadratic model for total viable count and biomass yield of L. helveticus MTCC 5463 grown in cheese whey

\begin{tabular}{|l|l|l|}
\hline Partial Coefficients & Dry biomass yield & TVC \\
\hline Intercepts & 3.17 & 15.5 \\
\hline A- Level of yeast extract & $0.39^{*}$ & $0.48^{*}$ \\
\hline B- Level of proteose peptone & $0.066^{\mathrm{NS}}$ & $0.046^{\mathrm{NS}}$ \\
\hline $\mathrm{AB}$ & $0.23^{*}$ & $0.27^{\mathrm{NS}}$ \\
\hline $\mathrm{A}^{2}$ & $-0.19^{*}$ & $-0.65^{*}$ \\
\hline $\mathrm{B}^{2}$ & $-0.11^{*}$ & $-0.26^{\mathrm{NS}}$ \\
\hline Model F & $40.14^{*}$ & $4.49^{*}$ \\
\hline $\mathrm{R}^{2}$ & 0.9663 & 0.7624 \\
\hline $\mathrm{APV}$ & 20.726 & 6.029 \\
\hline
\end{tabular}

** Significant at $1 \%$ level $(\mathrm{P}<0.01)$, * Significant at 5\% level $(\mathrm{P}<0.05)$, NS: Non-significant

Figure.1 Growth pattern of Lb. helveticus MTCC 5463 in MRS, Skim milk and Cheese whey

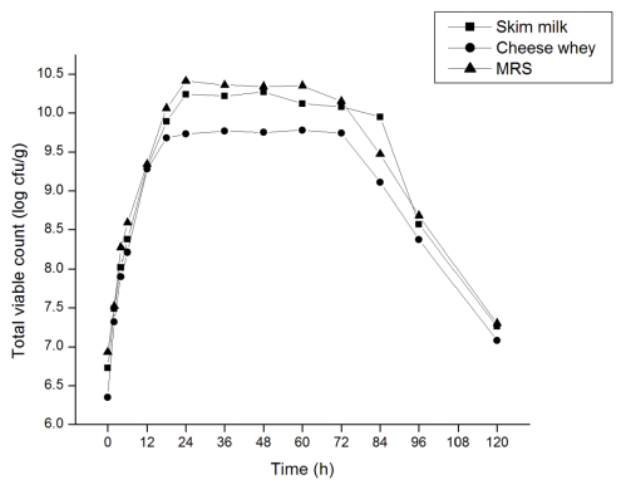


Figure.2 Changes in $\mathrm{pH}$ during fermentation of different media (MRS, Skim milk and Cheese whey)

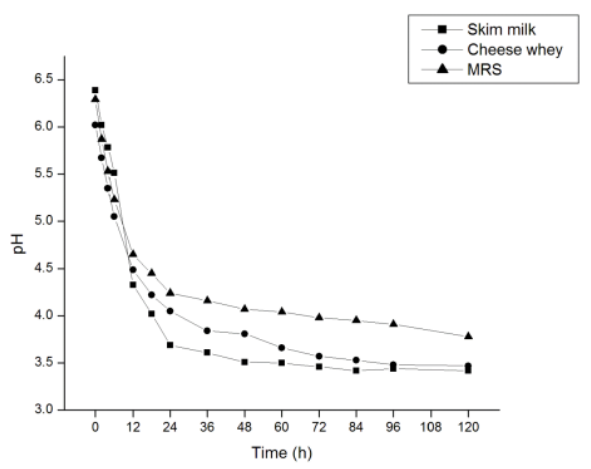

Figure.3 Surface response for effect of different growth parameters on TVC of L. helveticus MTCC 5463 grown in cheese whey; (a) Time and temperature (b) Time and pH (c) Temperature and $\mathrm{pH}$

a)

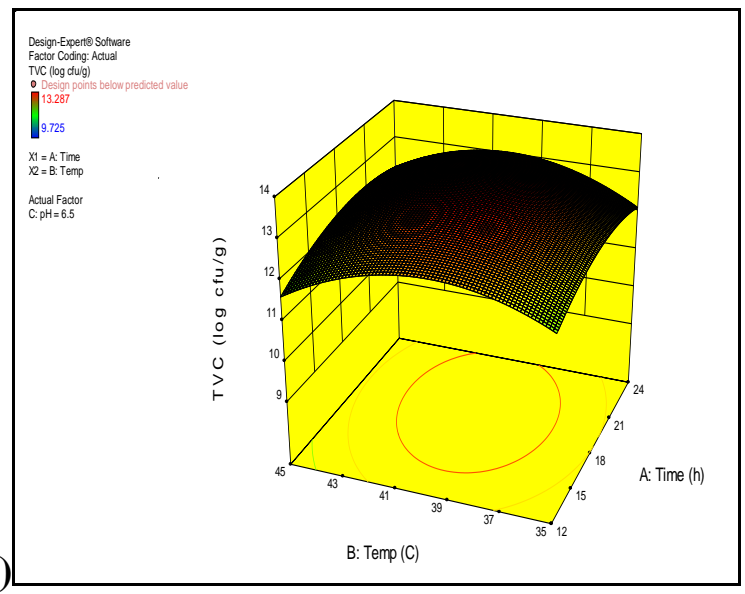

b)

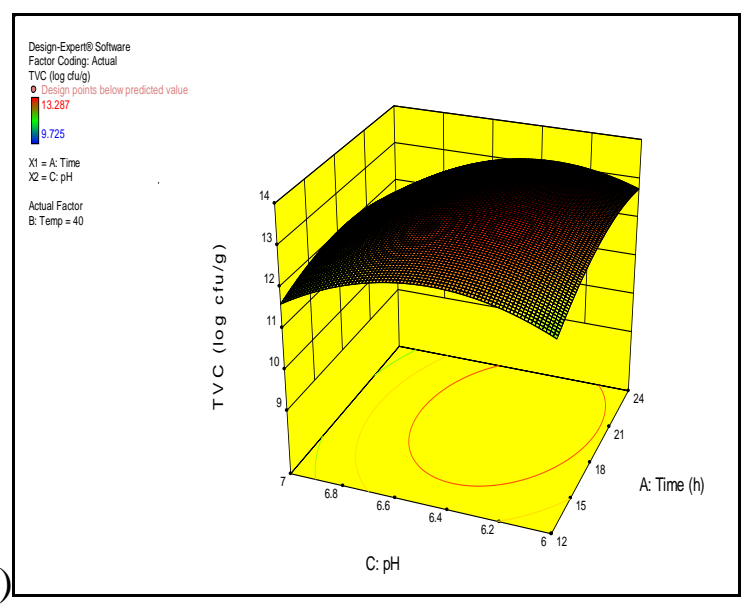

c)

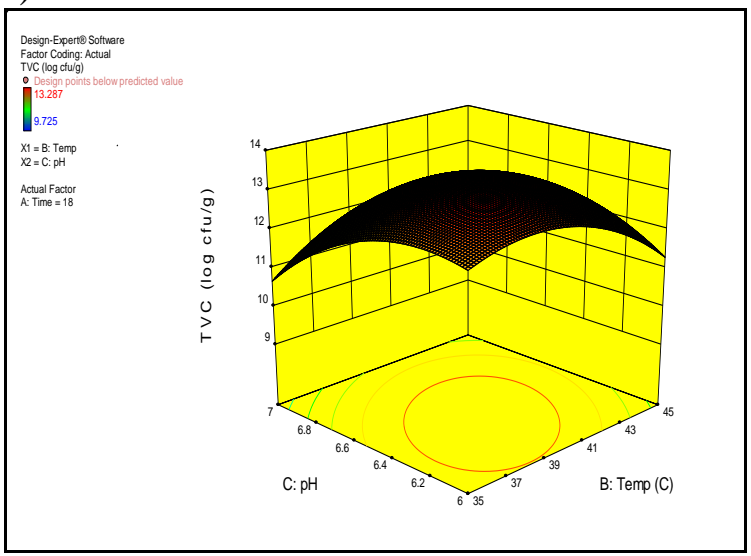


Figure.4 Surface response for effect of different growth parameters on biomass yield of $L$. helveticus MTCC 5463 grown in cheese whey; (a) Time and temperature (b) Time and pH (c)

Temperature and $\mathrm{pH}$

a)

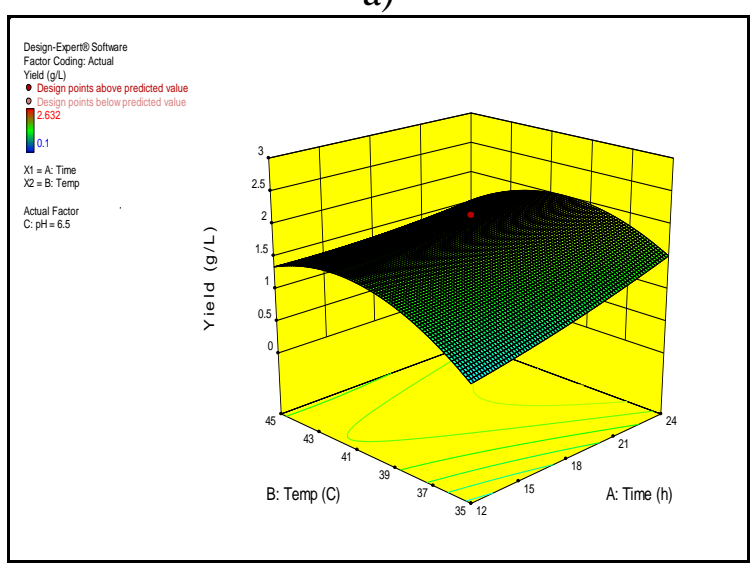

b)

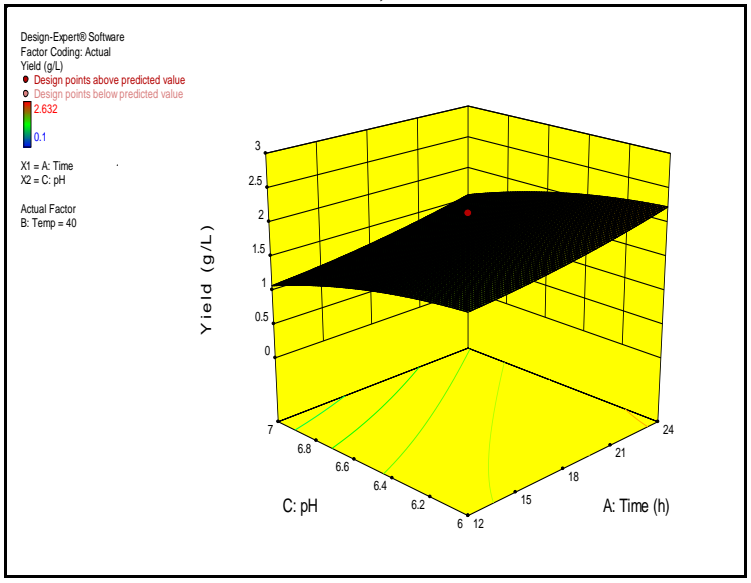

c)

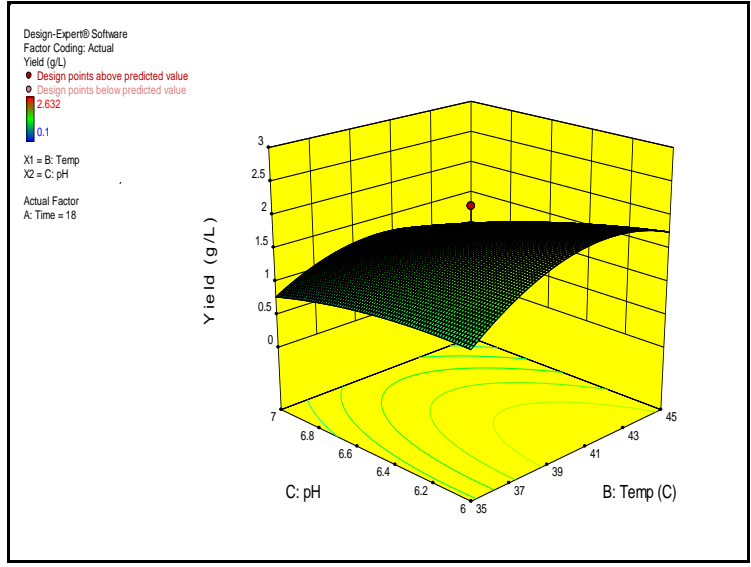


Figure.5 Surface response effects of different nutrient supplementation (yeast extract and proteose peptone) on TVC of L. helveticus MTCC 5463 grown in cheese whey

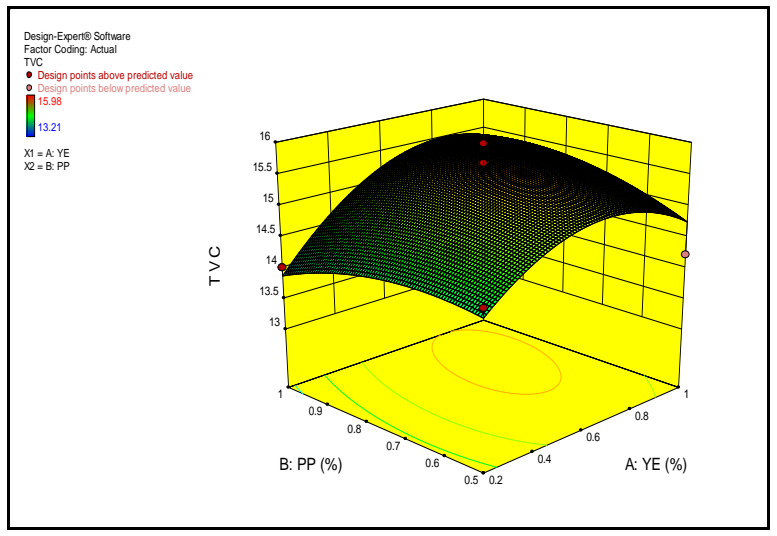

Figure.6 Surface response effects of different nutrient supplementation (yeast extract and proteose peptone) on biomass yield of L. helveticus MTCC 5463 grown in cheese whey

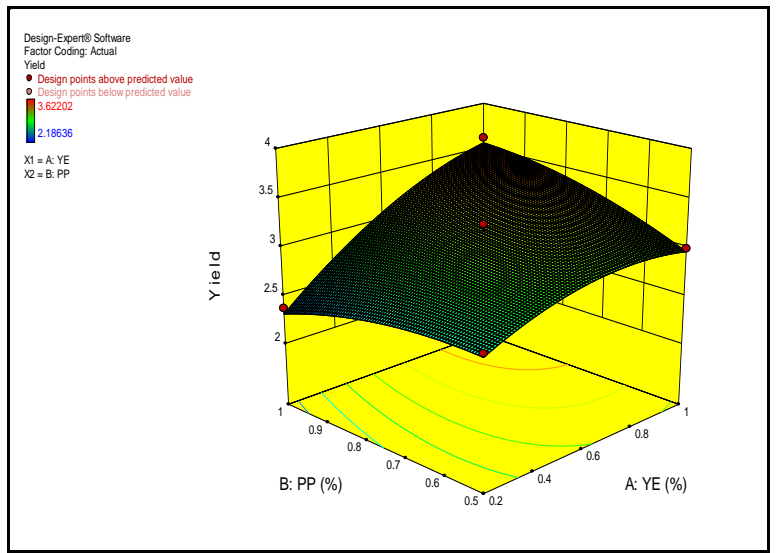

The major influence of $\mathrm{pH}$ over biomass production in fermentation processes is due to the fact that the catalytic activity of the enzymes and metabolic activity of the microorganism depend on extracellular $\mathrm{pH}$. According to Hofvendahl and Hahn-Hägerdal (2000) and Wood and Holzapfel (1995), optimal $\mathrm{pH}$ for lactic acid production by lactic acid bacteria varies between 5.0 and 7.0 and is dependent on the strain which is in accordance with the results obtained in this study ( $\mathrm{pH}$ 6.25) for L. helveticus MTCC 5463. Also it is indicated in Bergey's manual (Bergey et al., 1974) that the optimum temperature for lactobacilli ranges from 30
${ }^{\circ} \mathrm{C}-40{ }^{\circ} \mathrm{C}$ and $\mathrm{pH}$ from 5.5 -6.2. Similarly, the optimum temperature for highest viable biomass production was found to be $40{ }^{\circ} \mathrm{C}$. This result is in agreement with observation reported by Tango and Ghaly (1999) mentioning that maximum biomass was obtained at $42{ }^{\circ} \mathrm{C}$. However, slightly higher temperature $\left(45^{\circ} \mathrm{C}\right)$ was also reported by other researchers for L. helveticus (Kulozik and Wilde, 1999). This may be attributed to strain to strain to variation. On the basis of the results, further trials for the biomass production of $L$. helveticus MTCC 5463 were taken keeping temperature at $40{ }^{\circ} \mathrm{C}, \mathrm{pH}$ at 6.25 and incubation period of 24 hours. 
Effect of nutrient supplementation on biomass production

An RSM experiment was framed on the Central Composite Rotatable Design (CCRD) with two factors viz., Yeast extract and Proteose peptone. The 13 experiments so generated by the Design Expert 9.0.2 software were run and the corresponding response in terms of TVC $\log \mathrm{cfu} / \mathrm{g}$ and Dry Biomass yield $\mathrm{g} / \mathrm{L}$ was obtained after running the trials in biofermenter (Table 3).

\section{Effect on TVC}

The results obtained are shown in table 3 . The average TVC of L. helveticus MTCC 5463 varied from 13.21 to $15.98 \log \mathrm{cfu} / \mathrm{g}$. Total viable count was minimum (13.21 log cfu/g) when the strain was fermented in cheese whey supplemented with $0.03 \%$ YE and $0.75 \%$ PP at optimized growth parameters whereas maximum TVC of $15.98 \mathrm{log} \mathrm{cfu} / \mathrm{g}$ was obtained when cheese whey was supplemented with $0.6 \% \mathrm{YE}$ and $0.75 \% \mathrm{PP}$.

Better fit of quadratic model for TVC of the L. helveticus MTCC 5463 was explained on the basis of regression analysis of the data presented in table 4. Coefficient of determination $\left(\mathrm{R}^{2}\right), \quad 0.7624$ is in close agreement with adjusted $R^{2}$ of 0.5926 . This validates experimental and predicted levels of total viable counts. Higher model F value 4.49 than tabulated $F$ value supported the significance of model for predicting the effect of variables on TVC of $L$. helveticus MTCC 5463. Furthermore, higher adequate precision value (APV) (6.029) than required value (4.00) indicated the high and adequate prediction ability of the model. Surface response effects are shown in figure 5 . Multiple regression equation generated to predict the TVC as affected by different factors in terms of coded factor is given below:
Total Viable counts $=+15.5+0.48^{*} \mathrm{~A}+0.046^{*}$ $\mathrm{B}+0.27^{*} \mathrm{AB}-0.65^{*} \mathrm{~A}^{\wedge} 2-0.26^{*} \mathrm{~B}^{\wedge} 2$

\section{Effect on biomass}

Cheese whey supplemented with $0.03 \%$ YE and $0.75 \%$ PP showed minimal dry yield of $2.186 \mathrm{~g} / \mathrm{L}$ whereas maximum dry yield of $3.622 \mathrm{~g} / \mathrm{L}$ was found in medium supplemented with $1 \% \mathrm{YE}$ and $1 \% \mathrm{PP}$ and fermented at $40^{\circ} \mathrm{C}$ for 24 hours.

The regression analysis of the data presented in table 4 indicated that the coefficient of determination $\left(\mathrm{R}^{2}\right)$ was 0.9663 and that the model was significant. The ANOVA of quadratic model showed that model $\mathrm{F}$ value of 40.14 was more than the tabulated value. Adequate precision value (APV) was 20.726, which was significantly higher than minimum desirable (4.00) for high prediction value. All these parameters showed that model can be used to describe the effect of variables on biomass production of $L$. helveticus MTCC 5463 grown in cheese whey.

The coefficient estimates of dry biomass model (Table 4) showed that supplementation of cheese whey with YE and PP showed significant $(P<0.05)$ positive effect on yield at linear level. However, at quadratic level, both YE and PP did impart significant $(P<0.05)$ negative effect on yield of $L$. helveticus MTCC 5463. Interaction of all variables with each other also imparted positive significant effect on yield $(P<0.05)$. Surface responses for interactive effect of variables on yield are shown in figure 6.

Multiple regression equation generated to predict the biomass yield as affected by different factors in terms of coded factor is given below:

Biomass yield $=+3.17+0.39 * \mathrm{~A}+0.066^{*}$ $\mathrm{B}+0.23^{*} \mathrm{AB}-0.19^{*} \mathrm{~A}^{\wedge} 2-0.11^{*} \mathrm{~B}^{\wedge} 2$ 
The optimized value for level of YE and PP i.e. $0.95 \%(w / v)$ for each, were slightly higher than the level of supplementation reported by Masuda et al., (2006). On the other hand, the level optimized for different media constituents in the present study are found to be less than the data reported by other researchers (Liew et al., 2005; Bevilacqua et al., 2008; Chang and Liew, 2012). The difference found in the studies regarding level of $\mathrm{YE}$ and $\mathrm{PP}$ to obtain maximum biomass production from lactobacilli may be mainly due to addition of other ingredients such as glucose, meat extract, tryptone, casein or other protein hydrolysates and salts along with YE and PP which may provide growth nutrients to lactobacilli and thereby reduces the requirement of YE and PP. Nevertheless, from commercialization point of view, cost may be considered as one of the important factor for selection of different nitrogen and carbon source to be used as media supplementation. Also the quantity of growth nutrients available in base media (nonsupplemented) may also be considered as important factor for selecting a range of nutrients at different level of supplementation.

The stimulating effect of yeast extract on the growth of lactic acid bacteria is well known as yeast extract is a rich source of amino acids, peptides, nucleotides and group B vitamins, most of which are essential for stimulating the growth of lactobacilli (Møretrø et al., 1998). Our findings that PP, when used in combination with YE has a positive effect on growth of $L$. helveticus MTCC 5463 may have a number of explanations. Both the composition and average peptide length of complex nitrogen sources for bacteriological media differ widely (Oxoid Manual, 1990). However, since the proteolytic system of lactobacilli is similar to that of lactococci (Kunji et al., 1996) it is conceivable that, because of competition of $\mathrm{di}$, tri, and oligopeptide for the available carriers, increase of peptide concentration may not result automatically in increased growth. In fact, increased concentration of peptides whose amino acid composition is different from that required for balanced growth may limit the uptake of essential peptides and amino acids, thus resulting in growth limitation. Based on the results obtained from the experiment it was decided to supplement cheese whey by addition of yeast extract and proteose peptone at $0.95 \%$ (w/v) each to achieve the highest cell biomass.

The present study concluded that cheese whey supplemented with yeast extract and proteose peptone for the growth of probiotic $L$. helveticus MTCC 5463 showed the medium based on this low-cost by-product was suitable for producing high amount of cell biomass. In general, fermentation in this economical medium under optimized growth condition could be used as an alternative to the standard media (MRS broth), which appear to be too expensive for growing LAB on an industrial scale.

Cell biomass of L. helveticus MTCC 5463, an important microorganism recognized as an indigenous probiotic strain with maximum number of healthy living cells of the order of 14 $\log \mathrm{cfu} / \mathrm{g}$ was obtained by optimizing the process and parameters of fermentation. The whole experiment has helped in standardizing the conditions for de proteinated cheddar cheese whey fermentation for maximum biomass yield. Based on the results obtained in various phases, it could be concluded that cheddar cheese whey supplemented with $0.95 \%$ yeast extract and $0.95 \%$ proteose peptone, inoculated with $6 \%$ (v/v) active culture of L. helveticus MTCC 5463 and fermented for $24 \mathrm{~h}$ at temperature of $40{ }^{\circ} \mathrm{C}$ and $\mathrm{pH} 6.25$ could yield $3.25 \mathrm{~g} / \mathrm{L}$ dry cell biomass and $14.82 \mathrm{log} \mathrm{cfu} / \mathrm{g}$ total viable count.

\section{Acknowledgement}

I would like to extend my thanks to $3 \mathrm{M}$ India limited for awarding me fellowship during my research tenure and SMC college of Dairy Science, Anand Agricultural University, Anand for providing all the facilities.

\section{References}

Agarwal, L., Dutt, K., Meghwanshi, G.K. and Saxena, R.K. 2008. Anaerobic 
fermentative production of lactic acid using cheese whey and corn steep liquor. Biotechnol. Lett., 30: 631-635.

Agrawal, S., Garg, S.K. and Dutta, S.M. 1989. Microbial $\beta$-galactosidase: Production, properties and industrial applications. Int. J. Dairy Sci., 42: 251-262.

Altiok, D., Tokatli, F. and Harsa, S. 2006. Kinetic modeling of lactic acid production from whey by Lactobacillus casei (NRRL B-441). J. Chem. Technol. Biotechnol., 81: 1190-1197.

Alvarez, M.M., Aguirre-Ezkauriatza, E.J., Ramirez-Medrano, A. and RodriguezSanchez, A. 2010. Kinetic analysis and mathematical modeling of growth and lactic acid production of Lactobacillus casei var. rhamnosus in milk whey. $J$. Dairy Sci., 93: 5552-5560.

Ashar, M.N. and Prajapati, J.B. 1998. Bile tolerance, bile deconjugation and cholesterol reducing properties of dietary lactobacilli. Indian J. Microbiol., 38: 145-148.

Ashar, M.N. and Prajapati, J.B. 2000. Verification of hypocholesterolemic effect of fermented milk on human subjects with different cholesterol level. Folia Microbiol., 45: 263-268.

Bergey, D.H., Buchanan, R.E. and Gibbons, N.E. 1974. Bergeys manual of determinative bacteriology. Baltimore: Williams \& Wilkins.

Bevilacqua, A., Corbo, M.R.,Mastromatteo, M. and Sinigaglia, M. 2008. Combined effects of $\mathrm{pH}$, yeast extract, carbohydrates and di-ammonium hydrogen citrate on the biomass production and acidifying ability of a probiotic Lactobacillus plantarum strain, isolated from table olives, in a batch system. World J. Microbiol. Biotechnol., 24: 1721-1729.

Chang, C.P. and Liew, S.L. 2012. Growth medium optimization for biomass production of a probiotic bacterium, Lactobacillus rhamnosus ATCC 7469. J. Food Biochem., DOI: 10.1111/jfbc. 12004.

De Man, J.C., Rogosa, M. and Sharpe, M.E.
1960. A medium for the cultivation of lactobacilli. J. Appl. Bacteriol., 23: 130.

FAO/WHO. 2002. Guidelines for the evaluation of probiotics in food. Report of a joint FAO/WHO working group on drafting guidelines for the evaluation of probiotics in food, London.

Ghanadzadeh, H. and Ghorbanpour, M. 2012. Optimization of Ethanol Production from Cheese Whey Fermentation in a BatchAirlift Bioreactor. J. Bioengineering \& Biomed. Sci., 2: 1-6.

Gupte, A.M. and Nair, J.S. 2010. $\beta$ galactosidase production and ethanol fermentation from whey using kluyveromycesmarxianus NCIM 3551. J. Scientific and Industrial Res., 69: 855859.

Hofvendahl and Hahn-Hägerdal. 2000. Factors affecting the fermentative lactic acid production from renewable resources. Enzyme and Microbial Technol., 26: 87107

Khedkar, C.D., Dave, J.M. and Sannabhadti, S.S. 1990. Antibacterial activity of human strains of Lactobacillus acidophilus grown in milk against selected pathogenic and spoilage type bacteria. Cultured Dairy Product J., 25: 29-31.

Khedkar, C.D., Dave, J.M. and Sannabhadti, S.S. 1991. Incidence of Lactobacillus acidophilus in human vaginal and gastrointestinal tracts. Indian Journal of Comparative Microbiology, Immunol. Infection Dis., 12: 107-109.

Kulozik, U. and Wilde, J. 1999. Rapid lactic acid production at high cell concentration in whey ultrafiltrate by Lactobacillus helveticus. Enzyme and Microbial Technol., 24: 297-302.

Kunji, E.R.S., Mierau, I., Hagfing, A., Poolman, B. and Konings, W.N. 1996.Theproteolytic systems of lactic acid bacteria. Antonie van Leeuwenhoek, 70: 187-221.

Lechiancole, T., Ricciardi, A. and Parente, E. 2002. Optimization of media and fermentation conditions for the growth of Lactobacillus sakei. Annals of Microbiol., 
52: 257-274.

Liew, S.L., Ariff, A.B. and Raha, A.R.2005. Optimization of medium composition for the production of a probiotic microorganism, Lactobacillus rhamnosus, using response surface methodology. Int. J. Food Microbiol., 102: 137-142.

Liu, M., Ping, L.H., Wen, X.Y. and Quan, Y.Q. 2010. Optimization of the medium composition for production of Lactobacillus rhamnosus TUST006 by response surface methods. Modern Food Sci. Technol., 26: 717-720

Lund, B., Norddahl, B. and Ahring, B. 1992. Production of lactic acid from whey using hydrolysed whey protein as nitrogen source. Biotechnol. Let., 14(9): 851-856.

Masuda, T., Nagai, A., Suzuta, Y. and Itoh, T. 2006. A novel culture medium for Lactobacilli based on cheese whey. Milk Sci., 55: 23-29.

Møretro, T., Hagen, B.F. and Axelsson, L. 1998. A new, completely defined medium for meat lactobacilli. J. Appl. Microbiol., 85: 715722 .

Oxoid Manual. 1990. 6th edn.,Unipath Ltd., Basingstoke, England.

Panesar, P.S., Kennedy, J.F., Gandhi, D.N. and Bunko, K. 2006.Bioutilisation of whey for lactic acid production. Food Chem., 105: 1-14.

Panesar, P.S., Kennedy, J.F., Knill, C.J. and Kosseva, M.R. 2007. Applicability of pectateentrapped Lactobacillus casei cells for $\mathrm{L}(+)$ lactic acid production from whey. Appl. Microbiol. Biotechnol., 74: $35-42$.

Parada, M.E.M., Martínez, M.N., Ramírez, C.J., Mayer, J.G., Ordaz, N.R. and Urbina,
E.C.2006. Lactic Acid Bacteria production from whey. Appl. Biochem. Biotechnol., 134: 223-232.

Polak-Berecka, M., Waśko, A., KordowskaWiater, M., Podleśny, M., Targoński, Z. and Kubik-Komar, A.2010. Optimization of medium composition for enhancing growth of Lactobacillus rhamnosus PEN using response surface methodology. Polish J. Microbiol., 59: 113-118.

Richardson, G.H., Cheng, C.T. and Young, R. 1977. Lactic bulk culture system utilizing a whey-based bacteriophage inhibitory medium and pH control. J. Dairy Sci., 60: 378-384.

Shahbazi, A., Mims, M.R., Li, Y.B., Shirley, V., Ibrahim, S.A. and Morris, A. 2005. Lactic acid production from cheese whey by immobilized bacteria. Appl. Biochem. Biotechnol., 121: 529-540.

Tango, M.A. and Ghaly, A.E. 1999. Amelioration of lactic acid production from cheese whey using microaeration. Biomass and Bioenergy J., 17: 221-238.

Vishwanath, K., Prajapati, J.B. and Ljungh, A. 2012. Evaluation of adhesion of Lactobacillus strains to HT-29 cells by a flow cytometric assay. Int. J. Appl. Animal Sci., 1: 01-07.

Wood, B.J.D. and Holzapfel, W.H. 1995. The Genera of Lactic Acid Bacteria. Chapman and hall, London.

Youssef, C.B. and Goma, G. 2005. Kinetic modeling of Lactobacillus casei ssp. rhamnosus growth and lactic acid production in batch cultures under various medium conditions. Biotechnol. Lett., 27: $1785-1789$.

\section{How to cite this article:}

Salma, J.B. Prajapati, Subrota Hati, V. Sreeja and Jigar Trivedi. 2017. Deproteinated Cheese Whey Medium for Biomass Production of Probiotic Lactobacillus helveticus MTCC 5463. Int.J.Curr.Microbiol.App.Sci. 6(3): 174-187. doi: https://doi.org/10.20546/ijcmas.2017.603.019 